\title{
Acquiring Anatomical Representation of Human Maxilla for Rapid Maxillary Expansion Abstract
}

\begin{abstract}
The purpose of the study is to model and provide a better understanding of maxilla bone involved in the treatment for rapid maxillary expander (RME) for dento-facial applications. The treatment is recommended for patients presented with an arch width deficiency named cross bites. Cross bites often cause abnormal physical forces that disrupt the balance of the occlusal relationship. More commonly, the maxilla or the upper jaw appears to be narrow and contributes to significant degree of crowding in the mouth. Early investigators [1-4] discovered that rapid maxillary expansion resulted in a splitting of the median palatal suture. The expansion is possible with the process of bone resorption and new bone deposition thus maintaining the expansion achieved [10]. This preliminary study shows that the FE model has the potential to be a valuable tool for further analysis of dental simulation and the understanding of orthodontic treatment.
\end{abstract}

\begin{tabular}{|l|l|}
\hline Source & $\begin{array}{l}\text { 3rd Kuala Lumpur International Conference on Biomedical } \\
\text { Engineering 2006 }\end{array}$ \\
\hline Author & $\begin{array}{l}\text { ZABIR, F. A., ABDULLAH, A. S., ABU OSMAN, N. A., RADZI, } \\
\text { Z., YAHYA, N. A. \& ABU KASIM, N. H. }\end{array}$ \\
\hline ISSN & $1680-0737$ \\
\hline DOI & $978-3-540-69138-9$ \\
\hline Editor & $\begin{array}{l}\text { AbuOsman, N. A; Ibrahim, F; WanAbas, W. A. B. ;AbdulRahman, } \\
\text { H. S.; Ting, H. N. }\end{array}$ \\
\hline
\end{tabular}

\section{Keyword}

Dento-facial; maxillary expansion; automated; orthodontics; continuous force, FEM, SELFREPAIR; CULTURE-CONDITIONS; COMPOSITE RESIN; DENTAL PULP STEM CELL; FUNCTIONALLY GRADED DESIGN; MULTI LAYERED POST; FUNCTIONALLY GRADED DENTAL POST; SOFT SKILLS; CLINICAL PAIRING; DENTAL PULP STROMAL CELLS; LONG-TERM EXPANSION 


\section{Please Cite As}

ZABIR, F. A., ABDULLAH, A. S., ABU OSMAN, N. A., RADZI, Z., YAHYA, N. A. \& ABU KASIM, N. H. 2008. Acquiring Anatomical Representation of Human Maxilla for Rapid Maxillary Expansion. In: ABUOSMAN, N. A., IBRAHIM, F., WANABAS, W. A. B., ABDULRAHMAN, H. S. \& TING, H. N. (eds.) 4th Kuala Lumpur International Conference on Biomedical Engineering 2008, Vols 1 and 2. Kuala Lumpur: SPRINGER, 233 SPRING STREET, NEW YORK, NY 10013, UNITED STATES.

\section{URL}

http://www.springerlink.com/content/j334338673012216/

http://cmsad.um.edu.my/images/cab/doc/Publications/Proceeding2008/5.PDF

http://www.researcherid.com/rid/B-9275-2010 